\title{
Morphology of HRP-Injected Spinocervical Tract Neurons: Effect of Dorsal Rhizotomy
}

\author{
M. J. Sedivec, ${ }^{\star, 1}$ J. J. Capowski, $\dagger$ and L. M. Mendell ${ }^{\star}$ \\ *Department of Neurobiology and Behavior, SUNY at Stony Brook, Stony Brook, New York 11794, and \\ fDepartment of Physiology, University of North Carolina, Chapel Hill, North Carolina 27514
}

\begin{abstract}
Twenty-five physiologically identified spinocervical tract (SCT) neurons in the sixth lumbar segment of the cat were filled with HRP by intracellular injection. All were reconstructed from sagittal sections using the camera lucida, and a subset $(n=18)$ was also reconstructed using a computer reconstruction system. Thirteen cells were in intact preparations, nine were in spared root preparations (L5, L6, S1, S2 cut; L7 spared), and three were in preparations with L5 through $S 2$ cut. Analysis of the dendritic tree of these neurons revealed little change in gross morphology after partial deafferentation despite increased proportions sensitive to nociceptive input (Sedivec et al., 1983). The dendrites still largely respected the lamina II-III border, and relatively few dendrites were directed ventrally from the cell body, although the ratio of ventral to dorsal dendrites was greater than normal. The major change was an increase in surface area and volume caused by changes in diameter (but not length) of the dendrites. Larger-than-usual maximum branch order of individual dendritic trees of some cells was also observed after chronic deafferentation. Thus, SCT cells in deafferented segments do not undergo atrophy, but show, rather, limited signs of growth and the possibility of dendritic reorganization. We have also computed correlations between different parameters of these cells (cell body size, number and size of primary dendrites, total area and length of individual dendrites) and have found that, as in motoneurons, diameter of the primary dendrite measured $30 \mu \mathrm{m}$ from the soma is significantly correlated with total dendritic surface area and length. SCT neurons tend to have more dendrites than spinal alpha-motoneurons, but total surface area is smaller for a given diameter of a proximal dendrite.
\end{abstract}

Recently, we analyzed the physiological changes that occur after partial deafferentation of the spinal dorsal horn and found a reorganization of the submodality of cutaneous inputs to spinocervical tract cells (SCT). This population of large dorsal horn cells is located mainly in Rexed's (1952) lamina III and IV of the cat spinal cord (Brown et al., 1977a). We showed that, after partial deafferentation, an increased proportion of SCT cells lost their response to high-threshold input initially, but retained their response to low-threshold stimulation. Approximately 6 weeks

\footnotetext{
Received Jan. 25, 1985; revised May 21, 1985; accepted June 11, 1985

We thank Drs. Alan Light, H. Richard Koerber, and Louis Ritz for reading and commenting on a draft of this manuscript. Histological help was furnished by Carol Metz (Chapel Hill) and Carol Hall (Stony Brook). We thank Alan Light for his help in making Figure 1 and Dr. Nancy Mendell for help with the statistical procedures and evaluations. This work was supported principally by program project POI NS 14899 (E. R. Perl, P. I.). Some facilities were derived from R01 NS 16996 to L.M.M.

Correspondence should be addressed to Dr. Mendell.

Present address: Department of Biology, Appalachian State University, Boone, NC 28608.
}

Copyright (C) 1986 Society for Neuroscience $0270-6474 / 86 / 030661-12 \$ 02.00 / 0$ after deafferentation, a significantly greater proportion of cells began to respond to high-threshold input (Sedivec et al., 1983).

There are a number of possible reasons for the occurrence of such changes. (1) Since the submodalities that are undergoing change are mediated mainly by small-diameter fibers (Beitel and Dubner, 1976; Bessou and Perl, 1969; Burgess and Perl, 1967; Perl, 1968), a change in the afferent projection of these fine fibers may cause the observed change in modality input. (2) There may be a functional or morphological change in the intraspinal circuitry. (3) A change in the dendritic morphology of SCT cells may contribute to the observed modality reorganization. In this paper we focus on the most accessible of the possible changes, namely, SCT cell dendritic reorganization. Such a study is partly motivated by previous findings in diverse systems that suggested various types of dendritic reorganization following deafferentation (see Discussion). In the dorsal horn, dorsal rhizotomy in adults has been reported to cause either substantial dendritic atrophy (Brown et al., 1979) or no change (Brown et al., 1983). Brown et al.'s (1979) study was carried out using the Golgi method, which provides an incomplete view of cells whose identity (e.g., spinocervical, postsynaptic dorsal column, etc.) is unknown. The later study was performed using reconstructions of identified SCT neurons injected with HRP, but the analysis was limited to gross measurements of morphology of the dendritic tree. While this approach ensures a more uniform population for study, it should be kept in mind that SCT cells may not be representative of all types of dorsal horn cells.

The present study has also made use of identified SCT cells filled with HRP. However, we have extended previous findings by applying computer reconstruction to obtain a more quantitative evaluation of these cells in intact and partially deafferented preparations. Despite considerable variability in the dimensions of these cells in normal cords, we have demonstrated that certain measures of cell size undergo an increase in the partially deafferented dorsal horn. A preliminary account of this work has been published (Sedivec et al., 1982).

\section{Materials and Methods}

\section{Injection of SCT cells}

The SCT cells analyzed in this morphological study were obtained during an electrophysiological study (Sedivec et al., 1983). In the acute experiments, adult cats $(1.5-4.0 \mathrm{~kg})$ of either sex, either normal or partially deafferented (see below), were anesthetized with alpha-chloralose $(80 \mathrm{mg} / \mathrm{kg})$ administered intraperitoneally. The animal's arterial pressure, end-tidal $\mathrm{CO}_{2}$, and temperature were continuously monitored and maintained within normal limits (Sedivec et al., 1983). At the time of the intracellular recording and iontophoretic HRP injection, the animal was paralyzed with gallamine triethiodide (Flaxedil) and respirated through a tracheal cannula with positive pressure. While the animal was paralyzed, the depth of anesthesia was judged by monitoring blood pressure and pupillary constriction. The Flaxedil was allowed to wear 


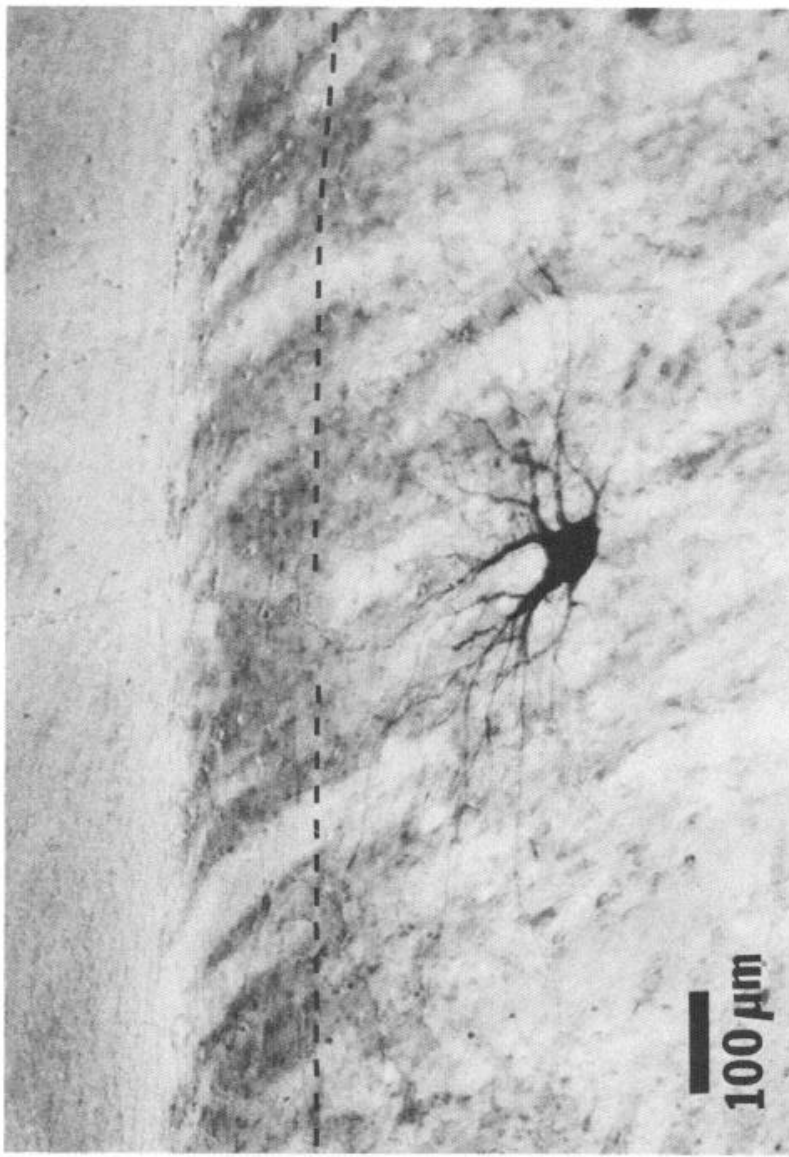

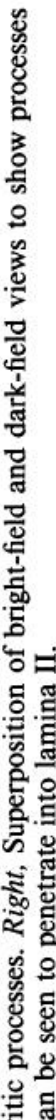

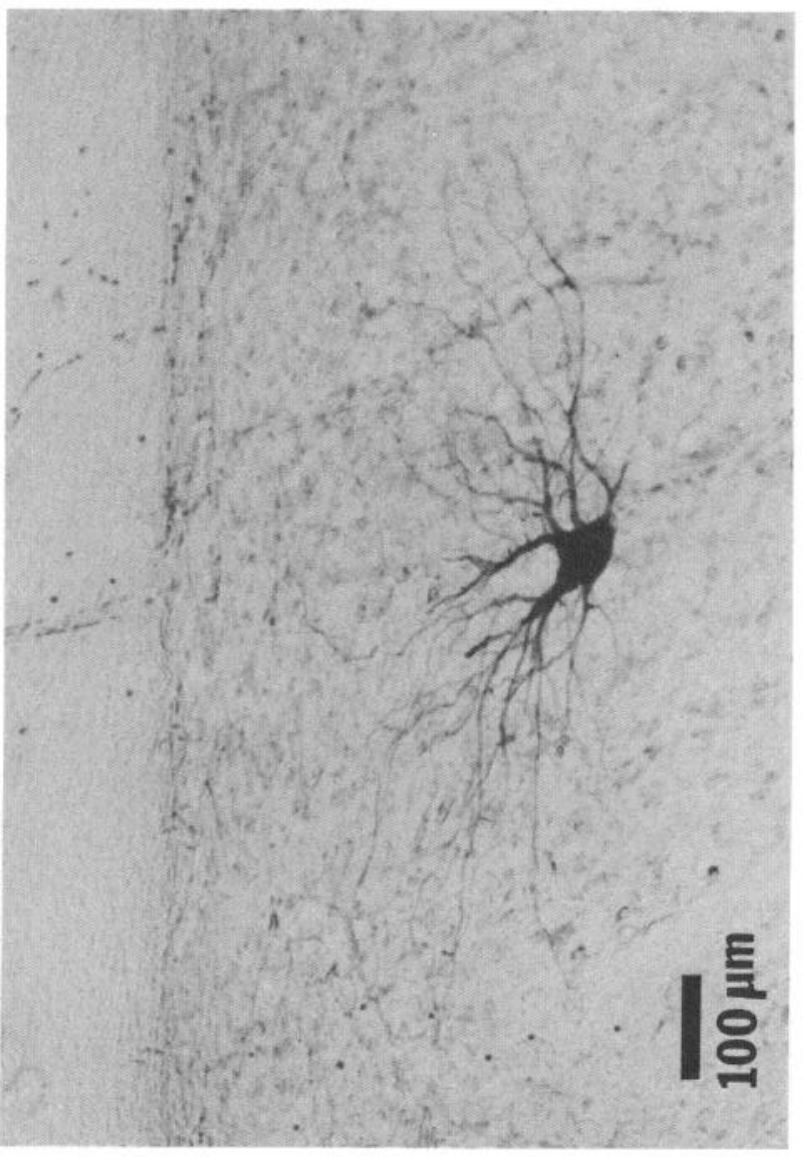

름

둥

ํㅗㄴ

品

폴

8

๒ํㅡ.

उ.

: 
off periodically to ensure anesthesia, which was supplemented as necessary through an intravenous cannula.

The microelectrodes used for recording and iontophoresis of HRP were broken micropipettes filled with Tris-buffered $0.5 \mathrm{M} \mathrm{KCl}$ solution (pH 7.3) containing approximately 10\% HRP (Sigma Type VI) and measuring 10-25 MS. SCT cells were identified by their response to an antidromic search stimulus, according to the criteria of Brown and Franz (1969) and Sedivec et al. (1983). Once an SCT cell was identified, its cutaneous receptive field was identified and modality input determined (see Sedivec et al., 1983). In most instances, this identification process was based on extracellular recording. The electrode was then deliberately manipulated (sometimes moved to another track) to increase the amplitude of the action potential (verifying the maintenance of the same unit by receptive field and antidromic latency analysis) evoked by antidromic electrical stimulation until a DC resting potential of at least $30 \mathrm{mV}$ was obtained. Intracellular penetration was also verified by the presence of EPSP activity during stimulation of the cell's cutaneous receptive field. On penetration, positive current $\left(4-20 \times 10^{-9}\right.$ A) was passed through the electrode by $5 \mathrm{msec}$ pulses (equal on and off duration) at a rate of $100 / \mathrm{sec}$ for a total of $1-10 \mathrm{~min}$.

\section{Histological procedures}

Two to nine hours after iontophoretic current passage, the animal was perfused, using a pressure system, via the carotid arterial cannula inserted earlier to monitor blood pressure. The chest was opened and the right atrium cut to allow evacuation of the perfusate. The initial perfusion fluid was 1 liter of $0.9 \% \mathrm{NaCl}$ solution containing $0.2 \%$ heparin and $0.1 \%$ xylocaine at $37^{\circ} \mathrm{C}$. This was followed by 4 liters of a $4^{\circ} \mathrm{C}$ solution of $0.5 \%$ paraformaldehyde and $2.5 \%$ glutaraldehyde in $0.1 \mathrm{~m}$ phosphate buffer $(\mathrm{pH} 7.3)$. The animal was then perfused with 1 liter of buffered $20 \%$ sucrose $(0.1 \mathrm{~m}$ phosphate buffer, $\mathrm{pH} 7.3)$. The L6 segment was removed from the animal and placed in buffered $30 \%$ sucrose until it sank. Parasagittal serial sections of the entire segment were cut on a freezing microtome at $80-100 \mu \mathrm{m}$ and collected in $0.1 \mathrm{M}$ phosphate buffer (pH 7.3). The sections were reacted for HRP for $30 \mathrm{~min}$ at room temperature in a solution of $0.05 \%$ diaminobenzidine tetrahydrochloride (Sigma grade II) and $1.0 \% \mathrm{H}_{2} \mathrm{O}_{2}$ in $0.05 \mathrm{M}$ Tris- $\mathrm{HCl}$ buffer, $\mathrm{pH} 7.6$. The sections were washed in three changes of $0.1 \mathrm{M}$ phosphate buffer, pH 7.3, for 10 min each and mounted conventionally. The sections were initially analyzed without counterstaining, and later, selected sections were counterstained with cresyl violet. Cytoarchitectonic borders were identified with dark-field microscopy, using cresyl violet sections (Fig. 1) (Rexed, 1952, 1954).

Of the SCT cells filled with HRP in this study, 25 neurons were sufficiently well stained to permit full reconstruction of their dendritic trees. The tissue was cut in the sagittal plane, which allows for a more complete analysis of the structure of the dendritic tree (Brown et al., 1977a). At the light-microscopic level, all 25 neurons appeared to be sufficiently stained. The more distal small dendrites were clearly visible, with most of the dendrites either tapering smoothly to a natural ending or ending in a small enlargement. The small dendritic spines, when present, appeared to be adequately filled.

\section{Analysis of filled neurons}

The filled cells were analyzed in several ways. Initially, detailed camera lucida reconstructions of the entire neuron (4-8 sections) in the sagittal plane were made, using a Leitz drawing tube and $40 \times$ objective. Using a computer-based data tablet, the total dendritic length of each neuron was determined. The dimensions of the neurons drawn with the camera lucida were not corrected for shrinkage or unwanted refraction (Glaser, 1982; and see below).

A much more detailed analysis was made of a subset of the stained cells with the use of a computerized neuron reconstruction system, located at the University of North Carolina, Chapel Hill, Department of Physiology (see Capowski and Sedivcc, 1981, for a dctailcd dcscription). In brief, the dendritic tree was entered into the computer as Cartesian coordinates by tracing the length of each dendritic process with a microscope equipped with stepping motors that were attached to the $x, y$ stage and focus axis. At predetermined points along the dendritic process (usually at $6 \mu \mathrm{m}$ intervals and at any anatomical feature), the computer captured the $x, y, z$ coordinates, the dendritic thickness, and an indicator marking the type of point (branch, spine, swelling, etc.). When the tracing of each dendritic tree piece was completed, a list of points was stored in the computer, comprising a mathematical model of that piece of tree. Because dendritic trees usually extend through

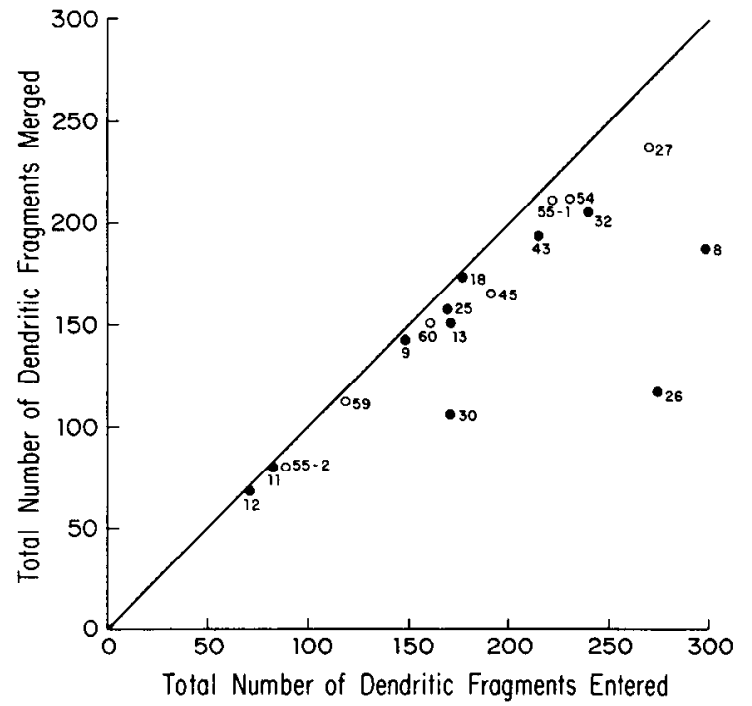

Figure 2. Graph showing the successful merging via the computer reconstruction system. The $x$-axis represents the total number of dendritic fragments of each cell entered into the computer before merging; the $y$-axis represents the number of dendritic fragments that could be merged. The diagonal line represents $100 \%$ merging success. All dendritic fragments were used to compute length and diameter values. Major bias introduced by failure to merge would be in branching order determinations (see text). O, L5, L6, S1, S2 cut; L7 spared. •, Intact.

several tissue sections, it was necessary to trace some dendrites in several pieces, a piece from each section. After all of the dendritic tree pieces in each of the tissue sections had been digitized and stored, the computer merged the cut ends of the dendrite in one section to their attachments in the next section, producing a three-dimensional mathematical model of all the intact dendrites in each cell. The problems of tissue shrinkage (histological processing) and unwanted refraction (Capowski and Sedivec, 1981; Glaser, 1982), which are additive and may vary in the range of 30-50\%, have been corrected for. A description of the problems associated with computer reconstruction can be found in Capowski (1985). The overall merging success rate was on the whole quite high in most cells (Fig. 2). The analysis of the branching order is the only parameter analyzed in this study that may have been influenced by the success of merging. If the merging success was below $85 \%$ ( 3 of 25 cells), the cells were not included in the branch point analysis. For the other analyses, we used all of the fragments, whether or not merging was possible.

Evaluation of differences between intact and deafferented preparations was carried out using parametric ( $t$ test) and nonparametric (MannWhitney $U$ ) statistics. Similar conclusions were reached from both types of tests; thus the results of parametric evaluations only are presented. Analysis of variance and regression analysis were performed as indicated in the text.

\section{Results}

\section{Location of sampled cells}

The present sample of 25 SCT cells recorded from the L6 segment was made up of the following: 13 cells from intact animals, nine cells from animals with L5, L6, S1, and S2 dorsal roots cut ipsilaterally (sparing L7), and three cells from animals with ipsilateral L5-S2 dorsal root lesions (see Sedivec et al., 1983, for a complete description of the sterile surgical techniques). Figure 3 shows the position of these cell bodies on a standard transverse section of the spinal cord. This was determined from sagittal sections by assessing position relative to the medial, lateral, and dorsal borders of the dorsal horn. The cell bodies of the 25 SCT cells were located exclusively in lamina III and IV of Rexed (1954). The location of this sample of SCT cells in the dorsal horn is similar to that of those studied by Brown et al. (1976, 1977a, 1980, 1983). 
Figure 3. Location of 25 intracellularly stained SCT cells in intact $(\mathbf{0} ; n=$ 13), partially deaffercnted (O, L5, L6, S1, and S2 cut, L7 spared; $n=9)$ and completely deafferented (a, L5, L6, L7, S1, S2 cut; $n=3$ ) cats. The position of each cell body has been placed on a standard transverse section of the dorsal horn according to its relative dorsoventral and mediolateral position. All cells were in the L6 segment. Roman numerals represent Rexed's laminae. The number next to each cell body location identifies the cell, some of whose parameters can be found in Table 1 .

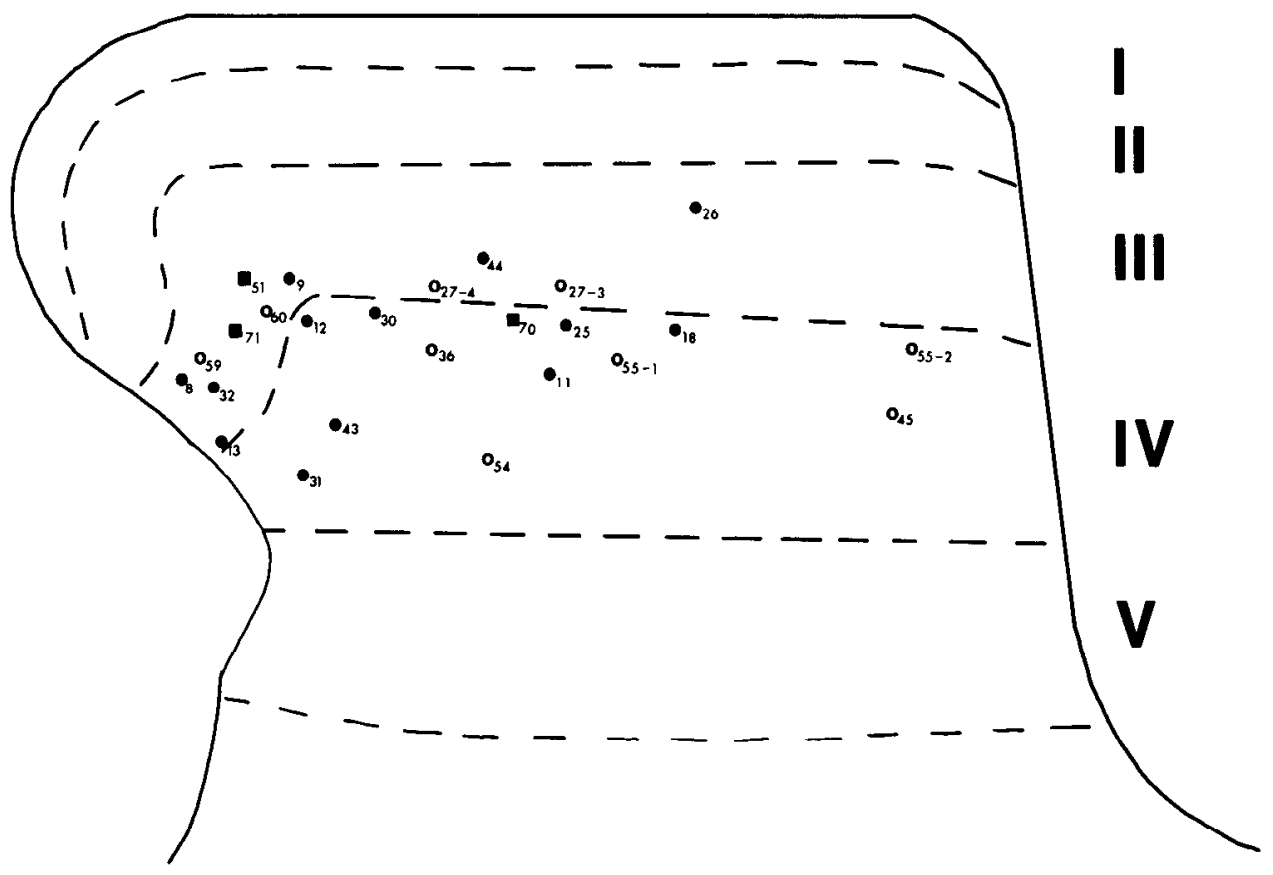

General cellular features of SCT cells from intact preparations

In agreement with the work of Brown et al. (1977a, 1983), we found SCT cells in intact preparations to be large neurons whose predominant dendritic orientation is rostrocaudal (Fig. 4). All cells had prominent, dorsally directed dendrites that, in counterstained sections, could be seen regularly to reach as far as the lamina II-III boundary. The dendrites of many cells (11/13) extended into inner lamina II, but only rarely $(2 / 11)$ as far as outer lamina II. Only two of 13 cells had significant dendritic area located ventrally from the cell body, although five of the remaining cells had one or two short dendrites coursing ventrally from the cell body. The cells' processes mediolaterally were relatively limited, as was evidenced by our finding that they were generally contained within three to four $100 \mu \mathrm{m}$ sagittal sections, and never more than in eight such sections. A more graphic view of this can be obtained from (computer) rotations of the cell from the sagittal into the horizontal plane (Fig. $4 B$ ). In Figure 4, it can be seen clearly that the mediolateral extent of the cell was highly limited. These views provide a clear representation of the columnar orientation of SCT cells. This ori- entation was maintained after all the deafferentation procedures carried out in thesc expcriments.

\section{Correlation of cell depth and physiology of SCT cells in intact and partially deafferented preparations}

Spinocervical tract cells have been shown to receive afferent input from peripheral receptors in the skin (Brown and Franz, 1969; Brown et al., 1976, 1977a; Sedivec et al., 1983). These cells, sampled in intact preparations, generally respond either to non-noxious stimuli only or to noxious as well as non-noxious stimulation (Brown and Franz, 1969; Mendell, 1966; Sedivec et al., 1983). Eight of the 13 SCT cells filled in intact preparations responded to non-noxious stimulation only: hair movement (six cells), moderate pressure only (one cell), or both modalities (one cell). Five units responded to noxious pinch in combination with hair movement and moderate pressure (four cells) or with hair movement only (one cell). In the chronically partially deafferented cord, virtually all cells (eight of nine) could be activated by noxious as well as non-noxious stimulation. This subset of filled cells in intact and in chronically deafferented preparations was thus representative of the much larger group of SCT cells
Figure 4. Computer plot of the reconstruction of a SCT cell displayed in $(A)$ the sagittal plane, and the same cell rotated approximately $90^{\circ}$ and displayed $(B)$ in the horizontal plane. Note that the dendrites have a columnar organization with very little spread in the mediolateral direction. The dendrites are drawn with their thickness shown. Note the dendritic spines and occasional swellings along the course of the processes.

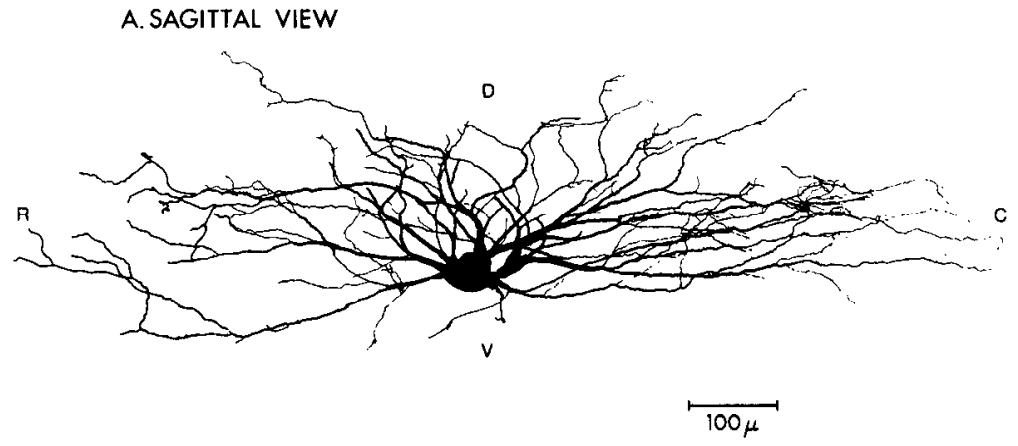

B. HORIZONTAL VIEW

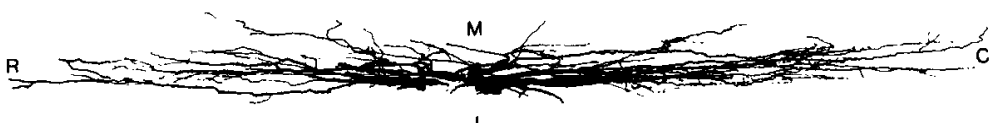




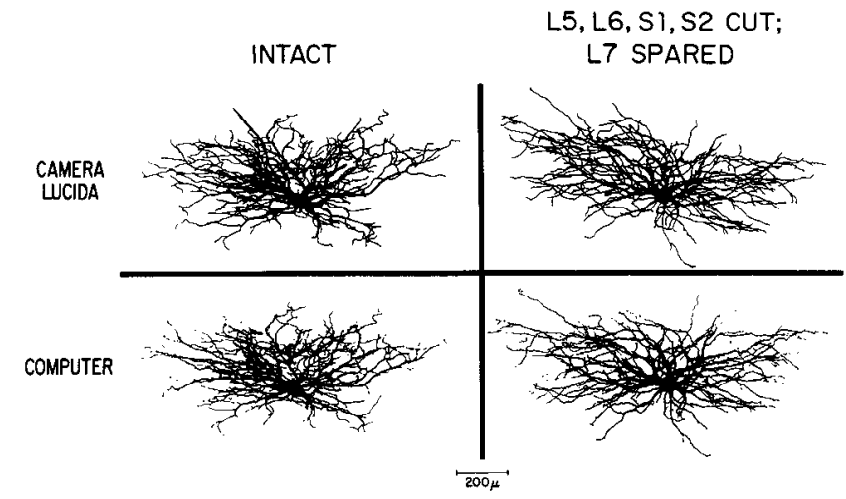

Figure 5. Camera lucida and computer reconstruction of two SCT cells from intact (left) and partially deaffcrentcd (right) spinal cord. At lcft is a cell from an intact preparation with the camera lucida reconstruction and computer reconstruction. Note the similarity in gross morphology of the two reconstructions. At right is a similar presentation of a cell from a partially deafferented preparation.

that were studied with extracellular recording, with respect to the modality of their input (Sedivec et al., 1983).

In intact preparations we found a marked tendency for SCT cells in lamina III to be responsive to non-noxious stimulation only (five of the six cells filled; only cell 32 responded to noxious stimulation). In lamina IV, only three of seven cells responded to non-noxious stimulation alone, while the remaining four (cells $1,18,31$, and 43) also responded to noxious stimulation. After partial deafferentation, all but one of the nine cells (cell 45) responded to noxious (and non-noxious) stimulation, even though four were located in lamina III.

\section{Morphological analysis of SCT cells in intact and in partially deafferented preparations}

Computer and camera lucida reconstructions were carried out by different individuals, using different microscopes; thus it was important to verify that the reconstructions obtained by both procedures were equivalent. The results obtained for two cells are shown in Figure 5; it can be seen that the general features of the cell are similar in both reconstructions. A more quantitative comparison emerges from consideration of total dendritic length, which ranged from 13,444 to $36,179 \mu \mathrm{m}$ in the 25 SCT cells analyzed with camera lucida reconstruction (Table 1) and from 20,247 to $53,428 \mu \mathrm{m}$ in the $18 \mathrm{SCT}$ units analyzed with computer reconstruction (Table 1 ). In the 18 cells analyzed using both reconstruction methods, it can be seen that the total dendritic length obtained by computer reconstruction was, on the average, 25\% larger than that obtaincd by camcra lucida reconstruction (Fig. 6; Table 1). A major factor underlying this difference is that camera lucida drawing represents a projection onto the sagittal plane, whereas the three-dimensional computer reconstruction provides a true length without projection, and also with correction for shrinkage, wrinkling, and unwanted refraction (Capowski, 1985; Capowski and Sedivec, 1981).

\section{Dendritic projections}

We examined the possibility that SCT cells responding to noxious pinch might extend their dorsal dendrites into outer lamina II and into lamina I, which have been shown to receive A-delta and C fiber input (Light and Perl, 1979a, b). Two cells (one responding to hair movement only and the other responding to hair, pressure, and noxious pinch) had dendritic extensions into lamina I and outer lamina II. The dendrites of the 11 remaining cells extended only as far as inner lamina II ( 9 cells) and lamina III ( 2 cells). Four of these still responded to noxious pinch. The ability of SCT cells to respond to noxious input is not correlated with the extent of their dorsal dendritic projections. In addition,

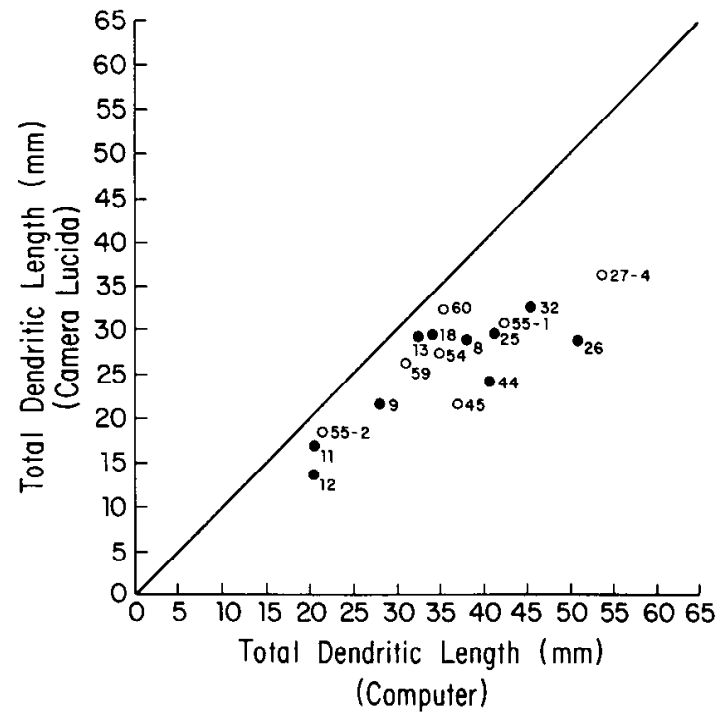

Figure 6. Comparison of total dendritic length obtained with camera lucida reconstruction technique and computer reconstruction method. Note that the total dendritic length of each cell, as measured with the computer, is consistently larger than the total dendritic length as measured using the camera lucida. The diagonal line represents equality of total dendritic length measured in both reconstructions. O, L5, L6, S1, S2 cut; L7 spared. - Intact.

no association was seen between the cell's ability to respond to noxious stimulation and the extent of the ventral projection, which might have been expected on the basis of the known termination of A-delta high-threshold mechanoreceptors in lamina V (Light and Perl, 1979a).

All but one of the nine SCT cells sampled after chronic partial deafferentation responded to noxious input. If the increase in

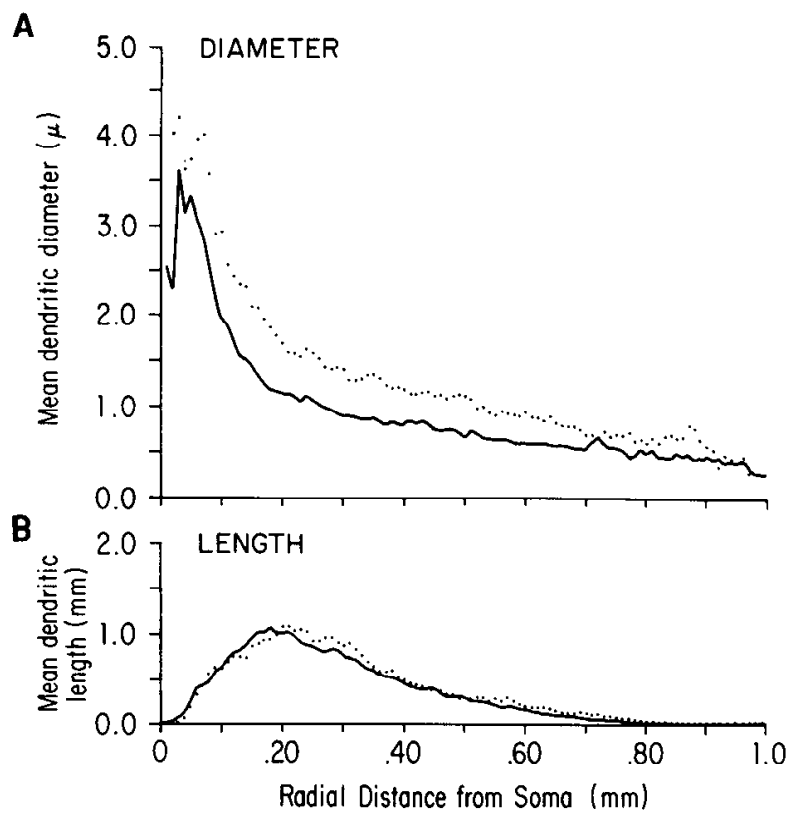

Figure 7. Graphs showing $(A)$ the mean diameter and $(B)$ mean dendritic length of cells from the intact $(n=11)$ and partially deafferented $(n=7)$ spinal cord. Note that the mean lengths are essentially the same at all distances from the soma, whereas the mean diameter is increased at virtually all radial distances from the cell body after deafferentation. The ordinate represents the mean value of the parameter (length or diameter) contained within a $10 \mu \mathrm{m}$ shell whose radius is represented by the abscissa. - . L5, L6, S1, S2 cut; L7 spared. -, Intact. 
Table 1. Properties of filled neurons

\begin{tabular}{|c|c|c|c|c|c|c|c|}
\hline Cell no. & $\begin{array}{l}\text { Total } \\
\text { dendritic } \\
\text { length } \\
(\mu \mathrm{m} \times 1000) \\
\text { (camera } \\
\text { lucida) }\end{array}$ & $\begin{array}{l}\text { Total } \\
\text { dendritic } \\
\text { length } \\
(\mu \mathrm{m} \times 1000) \\
\text { (computer) }\end{array}$ & $\begin{array}{l}\text { No. of } \\
\text { branch points } \\
\text { (computer) }\end{array}$ & $\begin{array}{l}\text { Highest } \\
\text { branch order } \\
\text { (computer) }\end{array}$ & $\begin{array}{l}\text { Weighted } \\
\text { mean } \\
\text { diameter }(\mu \mathrm{m}) \\
\text { (computer) }\end{array}$ & $\begin{array}{l}\text { Ratio of } \\
\text { ventral } \\
\text { to dorsal } \\
\text { dendritic } \\
\text { length } \\
\text { (computer) }\end{array}$ & $\begin{array}{l}\text { Ratio of } \\
\text { caudal to } \\
\text { rostral } \\
\text { dendritic } \\
\text { length } \\
\text { (computer) }\end{array}$ \\
\hline
\end{tabular}

\section{Intact preparation}

\begin{tabular}{|c|c|c|c|}
\hline 8 & 28 & 38 & - \\
\hline 32 & 33 & 46 & 402 \\
\hline 13 & 28 & 33 & 290 \\
\hline 9 & 22 & 28 & 170 \\
\hline 31 & 27 & - & - \\
\hline 12 & 13 & 20 & 191 \\
\hline 43 & 30 & 40 & 431 \\
\hline 30 & 27 & 29 & - \\
\hline 44 & 24 & - & - \\
\hline 11 & 17 & 20 & 169 \\
\hline 25 & 30 & 41 & 465 \\
\hline 18 & 30 & 34 & 334 \\
\hline 26 & 29 & 51 & - \\
\hline Mean \pm SEM & $26.0 \pm 1.5$ & $34.5 \pm 3.0$ & $307 \pm 43$ \\
\hline
\end{tabular}

"Partially" deafferented preparation (L5, L6, S1, S2 cut; L7 spared)

\begin{tabular}{|c|c|c|c|c|c|c|c|}
\hline 59 & 26 & 31 & 248 & 14 & 1.83 & 0.4 & 1.3 \\
\hline 60 & 32 & 36 & 194 & 13 & 1.22 & 0.4 & 2.0 \\
\hline $27-4$ & 36 & 53 & 423 & 19 & 1.37 & 0.0 & 1.9 \\
\hline $27-3$ & 31 & - & - & - & - & - & - \\
\hline $55-1$ & 31 & 43 & 435 & 24 & 1.79 & 0.25 & 0.8 \\
\hline 45 & 22 & 37 & 475 & 25 & 1.47 & 0.04 & 1.0 \\
\hline Mean \pm SEM & $26.5 \pm 2.0$ & $36.5 \pm 3.7$ & $333 \pm 47$ & $19.4 \pm 2.2$ & $1.60 \pm 0.25$ & $0.36 \pm 0.19$ & $1.25 \pm 0.19$ \\
\hline \multicolumn{8}{|c|}{ "Completely" deafferented preparation (L5, L6, L7, S1, S2 cut) } \\
\hline 71 & 30 & & & & & & \\
\hline 51 & 33 & & & & & & \\
\hline 70 & 25 & & & & & & \\
\hline
\end{tabular}

the proportion of units responding to noxious stimulation is due to a change in dendritic projection, one might expect the dendrites of these eight cells to reach lamina I and outer lamina II or lamina $V$. None of the eight cells sent dendrites into the most superficial layers. They reached only inner lamina II (four cells) or lamina III (four cells). However, our initial analysis suggested that some cells in spared root preparations might have unusually profuse ventral dendrites.

These issues were studied more carefully in 18 cells, using computer reconstruction. We calculated the length of all dendritic processes in each $30^{\circ}$ sector around the cell body, in sagittal scctions. Because these were projections onto the sagittal plane, each sector really represented the volume of a wedge subtended at the soma by a $30^{\circ}$ angle in the sagittal plane and extending indefinitely in the mediolateral direction. We then computed the proportion of dendritic length (as a fraction of total dendritic length) in the two sectors on either side of the dorsal projection axis from the cell body; similarly for ventral, caudal, and rostral projections. As would be expected from the general picture in Figures 1,4 , and 5 , we found that, for intact cells $(n=11)$, there was in general considerably more dendritic length extending dorsally from the cell than ventrally, but that caudal and rostral dendritic lengths, on the average, were about equal (Table 1). After chronic deafferentation, we observed increased ratios of ventral/dorsal and caudal/rostral dendritic length. Neither of these changes was found to be significant, using parametric $(p>$ 0.30 and 0.35 , respectively) or nonparametric statistics. The combination of these changes suggests that dendritic reorganization may occur to favor regions that maintain their input over regions that have lost theirs. In this case, the major loss would be from hair afferent fibers (Brown and Franz, 1969) entering in the L6 root and terminating primarily in lamina III (Brown et al., 1977b) dorsal to the SCT cell body; the portion of the dendritic tree with relatively enhanced input would be ventral (because of the loss of dorsal input from afferent fibers) and caudal (because L7 survives).

\section{Dendritic length and dendritic diameter}

The number of primary dendrites emanating from the cell body showed considerable variation from cell to cell, ranging from 10 to 25 in intact preparations and from 13 to 20 after partial 
deafferentation. No change was observed in the mean number of primary dendrites under the two experimental conditions $[17 \pm 2$ (SEM) for intact versus $16 \pm 1$ for deafferented; $p>0.5]$.

Using computer reconstruction, we computed the mean total dendritic length (i.e., averaged over all cells in each treatment group) in shells of $10 \mu \mathrm{m}$ thickness at a radius $r$ from the soma (as in a Sholl diagram). In Figure $7 B$, this mean length is represented on the ordinate and plotted against $r$ (on the abscissa). This polar representation implicitly assumes spherical symmetry, which clearly is not the most appropriate choice for cells of this shape. However, it requires only a single variable $(r)$, and is thus relatively simple.

With regard to dendritic length, it can be seen that the maximum incremental length is located at an average radial distance of about $200 \mu \mathrm{m}$ from the cell body. At small radial distances, all dendrites are represented, and as they begin to branch with increasing distance from the soma, the mean total length in each shcll increases. At greater distances from the soma, fewer and fewer dendrites contribute to dendritic length because they terminate; this explains the decrease in total length with increasing radial distance. Thus, the results in Figure $7 B$ should not be interpreted as indicating that maximum incremental length occurs $200 \mu \mathrm{m}$ from the cell body for all dendrites.

Mean diameter was weighted according to the length of process observed at each of the $n$ values of diameter (i.e., $d_{\text {mean }}=$ $\sum_{i=1}^{n} d_{i} \times l_{i} / \sum_{i=1}^{n} l_{i}$ ), and plotted as a function of radial distance (Fig. $7 A$ ). It is largest for dendrites close to the soma, falling off monotonically with increasing distance as the dendrites branch. The fact that dorsally and ventrally directed dendrites terminate at shorter radial distances than do rostrally and caudally directed ones may influence the rate of attenuation of mean dendritic diameter with increasing radial distance.

An analysis of the mean dendritic length at given radial distances from the soma showed that the SCT cells in the intact $(n=11)$ and partially deafferented $(n=7)$ segments were virtually indistinguishable (Fig. $7 B$ ). Even the three SCT cells in preparations subject to more complete deafferentation (L5 through $\mathrm{S} 2$ cut) showed no evidence of change in dendritic length (Table $1, p>0.3$ ), although no computer reconstruction was undertaken on these neurons. In contrast, after partial deafferentation the mean diameter was found to be consistently elevated compared to normal at all radial distances from the soma, with the exception of the greatest distances, i.e., between 0.9 and $1.0 \mathrm{~mm}$ (Fig. $7 \mathrm{~A}$ ). In accordance with this, the average mean dendritic diameter (calculated over all dendrites for each cell) was found to be smaller in intact cords $(1.20 \pm 0.11 \mu \mathrm{m} \mathrm{SEM}$; $n=11)$ than in partially deafferented cords $(1.60 \pm 0.20 \mu \mathrm{m}$ SEM; $n=7 ; p<0.06)$. The three cells with the largest mean dendritic diameter were from deafferented preparations, and the three smallest cells were from intact preparations (Table 1). These findings support the view that the increases in diameter, although small, were not the result of a single unusual cell in one of the groups.

By treating the dendritic tree as a series of cylinders whose diameters could vary at each observation point (see Methods), it was possible to derive the total surface area and total volume of each dendritic tree of each cell. This involved measuring the length $(l)$ and diameter $(d)$ of each segment and calculating its surface area $(\pi d l)$ and volume $\left(\pi d^{2} / 4 l\right)$, after which the total surface area and volume could be obtained by summation. Mean surface area of dendritic trees was larger for partially deafferented cells than for cells in intact preparations (18 $\pm 2 \times 10^{4}$ $\mu \mathrm{m}^{2}$ (SEM) versus $\left.12 \pm 2 \times 10^{4} \mu \mathrm{m}^{2} ; p<0.05\right)$. Furthermore, in Figure 8 it can be seen that the mean surface area and volume of dendritic processes measured at different radial distances from the soma were consistently larger in partially deafferented neu-
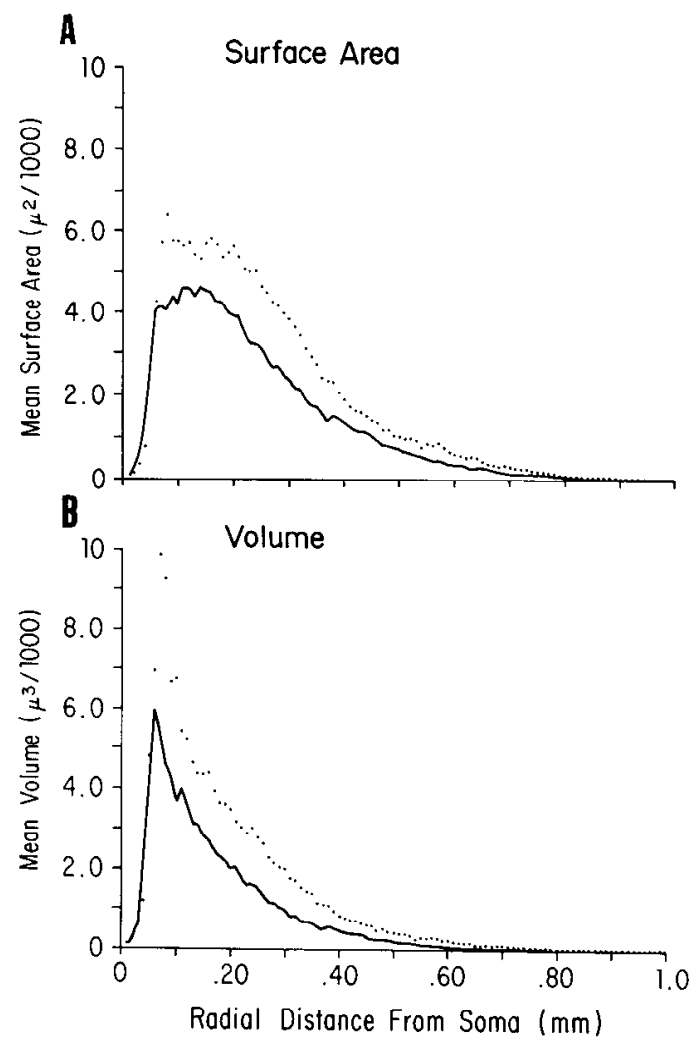

Figure 8 . Graphs showing $(A)$ the mean surface area and $(B)$ volume vs radial distance from the cell body in intact $(-; n=11)$ and partially deafferented ( $\cdots ; n=7$ ) spinal cord. See legend of Figure 7 and text for more details. Note that the cells from the partially deafferented spinal cord had a greater mean surface area and mean volume at all radial distances than those in the intact preparations. These differences are attributed to the increase in dendritic diameter.

rons. Our measurements of length and diameter suggest that increases in the latter cause the elevation of surface area and volume.

To control for differences in the number of dendritic trees of SCT cells, which would influence determination of whole cell parameters, we compared mean length, surface area, and volume per dendritic tree for each neuron across treatment conditions (i.e., intact, partially deafferented). We used a nested analysis of variance design (i.e., cells in intact and deafferented preparations, dendrites on each cell) to evalulate these data. We found a nonsignificant increase in mean dendritic length (1.66 \pm 0.22 to $2.19 \pm 0.22 \mu \mathrm{m} ; p>0.1$ ), but significant increases in mean surface area $\left(7.16 \pm 1.24 \mu \mathrm{m}^{2} / 1000\right.$ to $11.64 \pm$ $\left.1.20 \mu \mathrm{m}^{2} / 1000 ; p<0.02\right)$ and mean volume $(5.04 \pm 0.51$ $\mu \mathrm{m}^{3} / 1000$ to $\left.9.54 \pm 1.02 \mu \mathrm{m}^{3} / 1000 ; p<0.01\right)$ per dendritic tree. We interpret these changes in surface area and volume as resulting primarily from increased diameter than length of the dendritic processes.

\section{Analysis of branch points}

Individual dendrites were seen to branch profusely as they coursed away from the soma. In intact preparations, the mean number of branch points per cell, using only those cells with good merging success (Fig. 3) was $307 \pm 43$ (Table 1). Consideration of branching order of each dendrite emerging from the cell body revealed a mean maximum branch order for dendrites of cells in intact preparations of $16.8( \pm 0.8 ; n=11$; Table 1$)$, with a range from 13 to 21 . In partially deafferented preparations $(n=7)$, the mean number of branch points $(333 \pm 47$; Table 

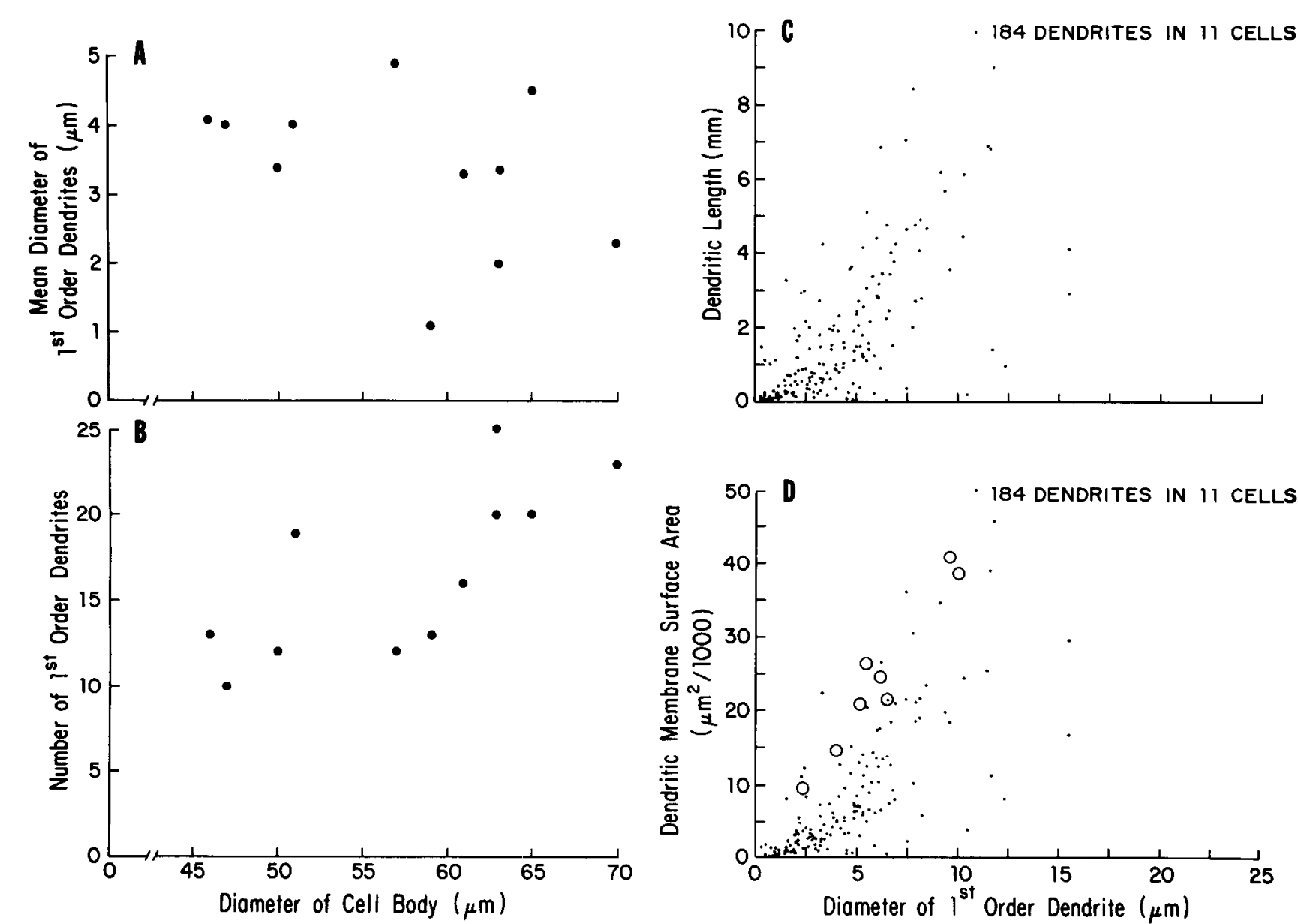

Figure 9. A, Relationship hetween mean diameter of first-order dendrites and diameter of the cell body. $B$, Relationship between number of firstorder dendrites and diameter of cell body. $C$, Relationship between (mean) dendritic length (total length of each first-order dendrite) and diameter of first-order dendrite. $D$, Relationship between surface area of entire dendrite and diameter of first-order dendrite. Large circles, Values obtained for eight alpha-motoneuron dendrites by Ulfhake and Kellerth (1981, Fig. 10). Two other dendrites analyzcd by these authors are not shown because their surface areas exceeded any found in the present study and could not be placed on this graph.

1) was only marginally higher than in intact preparations $(p>$ 0.6 ). The mean maximum branching order for individual dendrites of cells in partially deafferented preparations was 19.4 $( \pm 2.2 ; n=7$; Table 1$)$, with a range from 13 to 25 . Three cells in partially deafferented preparations exhibited dendrites with unusually large amounts of branching compared to normal (branch orders of 24,25 , and 25 ). They did not have unusually long dendrites, but two of these cells $(54,55-1)$ were at the upper end of the spectrum of mean dendritic diameter (Table 1).

\section{Comparison of dendritic parameters of SCT cells and alpha-motoneurons}

In recent years, it has become apparent that to better understand the integrative properties of vertebrate central neurons, it is necessary to know more about the morphology of their dendrites. The spread of synaptic currents within the dendrites and across the soma membrane is influenced by the geometrical structure of the dendritic tree. Quantitative studies of dendritic morphology have also provided a basis for the development of mathematical cable models, which have aided in the understanding of dendritic integrative properties (see review by Rall, 1977). The cell type whose dendritic morphology has been most frequently studied is the cal spinal alpha-motoneuron stained with HRP (Ulfhake and Kellerth, 1981; Zwaagstra and Kernell, 1981). A similar analysis was conducted on the 11 SCT cells from intact spinal cords (Figs. 9 and 10) to determine if anal- ogous correlations were present. If this were the case, it might suggest some general principles of cell and dendritic organization, at least for these large cells.

\section{Cell bodies and first-order dendrites}

In the $11 \mathrm{SCT}$ cells from intact preparations analyzed with the aid of the computer, the average value for mean cell body diameter, $d=(c / \pi)$, where $c$ is circumference, was $57.5 \mu \mathrm{m}( \pm 2.39$ SEM), with a range of 46-70 $\mu \mathrm{m}$. The size of these somata was similar to those studied by Brown and colleagues (Brown, 1981, p. 90). The mean number of first-order dendrites orginating from the cell body was 16.7 ( $\pm 1.5 \mathrm{SEM}$; range, $10-25 ; n=184)$, which is somewhat larger than for alpha-motoneurons (range, $8-15)$. The diameter of the first-order dendrites measured 30 $\mu \mathrm{m}$ away from the cell body-as measured in alpha-motoneurons by Ulfhake and Kellerth (1981)-ranged from 0.3 to 15.5 $\mu \mathrm{m}$, with a mean value of $4.03( \pm 0.22 \mu \mathrm{m} ; n=184)$. No correlation was obtained between the soma diameter and the mean diameter of the first-order dendrites $(r=0.38 ; p>0.01$; $n=11$ ) (Fig. 9A). There was, however, a significant positive correlation $(r=0.75 ; p<0.01 ; n=11)$ between the diameter of the cell body and the number of first-order dendrites (Fig. $9 B$ ). SCT neurons seem to differ from alpha-motoneurons in these respects, since in the latter there was a significant correlation between cell body diameter and the mean diameter of first-order dendrites but none between cell body diameter and 
the number of first-order dendrites (Ulfhake and Kellerth, 1981; Zwaagstra and Kernell, 1981).

\section{Dendritic dimensions}

In agreement with the findings in alpha-motoneurons (Ulfhake and Kellerth, 1984), a positive correlation was obtained when relating the diameter of the first-order dendrite to the total dendritic length (Fig. $9 C ; r=0.69 ; p<0.01$ ). A positive correlation was also obtained when relating the diameter of the first-order dendrite to the dendritic surface area (Fig. $9 D ; p=0.76 ; p<$ 0.01 ), as in alpha-motoneurons (Ulfhake and Kellerth, 1982, 1984). Similar relationships were found after chronic dorsal rhizotomy (not illustrated).

\section{Dendritic tapering}

The diameter of the proximal and distal ends of each dendritic segment (portion of dendrite between two branch points) was measurcd and the ratio (distal diameter/proximal diameter) calculated. The ratios for all dendritic segments in all dendrites for each cell were then plotted against the radial distances of these segments from the soma. A ratio of less than 1 would indicate that that particular segment was tapering. A typical SCT cell (cell 43) is represented in Figure 10A. Some segments in this cell showed an increase in diameter (ratio $>1$ ) rather than a decrease; on the average, however, only a small amount of taper was observed.

\section{Diameter changes at branch points}

In several theoretical studies where the dendritic trees of motoneurons have been reduced to equivalent cylinders (for reviews, see Rall, 1977; Redman, 1976), one underlying assumption has been that the ratio $\sum_{i=1}^{n}\left(d_{i}\right)^{3 / 2} / D^{3 / 2}$, where $D$ is the diameter of a dendrite segment, and $d$ corresponds to the diameter of each of its $n$ daughter branches, equals 1.0. In this study, we analyzed 1929 dendritic branching points from 10 SCT cells in intact spinal cords (located both proximally and distally in the dendritic tree) with respect to this ratio and obtained a mean value of $1.23 \pm 0.01$. This value is slightly, although significantly, greater than $1(p<0.001)$; SCT cells differ from motoneurons in this regard, since the latter exhibit values of $\sum_{i=1}^{n}\left(d_{i}\right)^{3 / 2} / D^{3 / 2}$ which are less than 1 (Ulfhake and Kellerth, 1981, 1984). In Figure $10 B$, the mean ratio $\sum_{i=1}^{n}\left(d_{i}\right)^{3 / 2} / D^{3 / 2}$ was calculated for the 1929 branch points as a function of their radial distances from the cell body. This ratio was increased in the more distal regions of the dendritic trees. Here, there was a greater degree of scatter, which probably resulted from the difficulty of measuring the diameters of the smallest distal dendrites.

\section{Discussion}

Computer reconstruction of SCT neurons has proved to be a relatively time-consuming task, preventing analysis of large numbers of cells. As a result of the small sample size, statistical tests have little power to detect small differences; thus, we may have underestimated the extent of changes occurring after chronic deafferentation. The advantage of this reconstruction method is that, once the cells have been "stored" in the computer, analyses can be undertaken with relative ease, permitting exhaustive determination of cell parameters (Figs. 9 and 10) and accurate comparisons between various populations of neurons (Figs. 7 and 8). These methods do not eliminate the problems inherent in quantitative analysis at LM level, particularly the limits of optical resolution: In these experiments, they were of the order

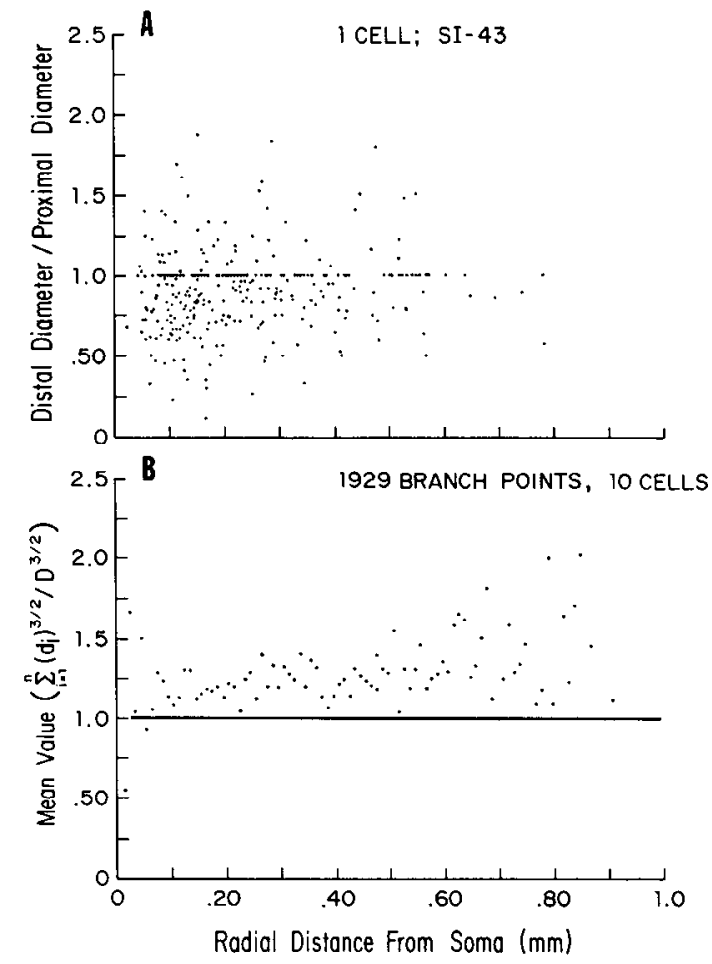

Figure 10. A, Relationship between the ratio (distal diameter/proximal diameter) for all dendritic segments for SCT cell 43 and the radial distance of these segments from the cell body. This cell represents a typical SCT neuron. Note that many segments show an increase in diameter (ratio 1). B, Graph illustrating the mean values for the ratio $\sum_{i=1}^{n}\left(d_{i}\right)^{3 / 2} / D^{3 / 2}$, where $D$ is the diameter of a dendritic segment and $d$ corresponds to the diameter of each of its daughter branches, for 1929 branch points ( 10 cells) in $10-\mu \mathrm{m}$-thick shells located increasing distances away from the cell body. Note that this ratio was consistently the same for most branch points from the SCT cells analyzed, except for the more distal regions of the dendritic trees.

of $0.3 \mu \mathrm{m}$. Measurement of dendritic diameter is particularly influenced by these considerations: The fact that differences between intact and deafferented preparations were observed at all distances from the cell body (Fig. 7A) indicates that this conclusion was not unduly influenced by optical resolution $-\mathrm{a}$ problem for the smallest processes located furthest from the soma (i.e., beyond $300 \mu \mathrm{m}$ from the soma).

Our results in SCT cells indicate certain correlations between soma size and dendritic properties (Fig. 9), which differ from those reported for alpha-motoneurons (Ulfhake and Kellerth, 1981). However, our measurements of somal diameter rely on assumptions of shape that may introduce inaccuracies (see Ulfhake, 1984, for discussion); therefore, these differences should be regarded as tentative. On the other hand, the diameter of the proximal dendrite measured $30 \mu \mathrm{m}$ from the soma is of some predictive value for estimating total dendritic process length, surface area, and volume, as in alpha-motoneurons. Although both cell types exhibit relationships between dendritic surface area and proximal dendritic diameter, the motoneurons studied by Ulfhake and Kellerth (1981) exhibit a larger dendritic surface area for a given proximal dendrite diameter than do SCT cells (Fig. 9D). This more than "compensates" for the smaller number of primary dendrites emanating from motoneuron cell bodies, since motoneurons are typically larger than SCT cells: $23-$ $64 \times 10^{4} \mu \mathrm{m}^{2}$ for motoneurons (Ulfhake and Kellerth, 1984) versus $11-26 \times 10^{4} \mu \mathrm{m}^{2}$ for SCT cells in the present material 
(both measurements include soma surface area). The " $3 / 2$ rule" appears to be satisfied, particularly at proximal branch points of SCT cells, as with motoneurons, and there can be moderate tapering in the SCT cell dendrites, as in motoneurons (Barrett and Crill, 1974; Zwaagstra and Kernell, 1981). Given these properties, the SCT cell would seem to be a reasonable candidate for application of the Rall cable model.

The morphological analysis of SCT cells suggests that the projection of dendrites into the most superficial layers of the dorsal horn (outer lamina II and I), which is a major termination site of nociceptive afferents (Light and Perl, 1979a, b), is not required in order for these cells to exhibit a response to noxious stimulation (see also Ritz and Greenspan, 1985). This suggests that some additional factor must be responsible for the responsiveness to noxious input of these cells in the intact preparation and, after chronic partial deafferentation, i.e., the spared root preparations, for the increased probability of responsiveness to these inputs. One factor may be that A-delta mechanical nociceptors can project directly to lamina V (Light and Perl, 1979b). Contact between these afferent fibers and SCT cells might become more likely if the ventral dendritic projections (Table 1) and/or axonal terminals of the afferent fibers were more profuse. Furthermore, it is now known that cells of lamina II project into lamina V (Light and Kavookjian, 1984); some component of this multisynaptic pathway might undergo adjustment after partial deafferentation.

Previous investigators have examined the morphology of dorsal horn neurons after similar conditions of chronic deafferentation. Brown and his colleagues (1979) reported that neurons in the $\mathrm{L} 7$ segment undergo severe atrophy of their dendritic tree when the L7 dorsal root is cut 3-224 d previously. Their studies were undertaken on unidentified, Golgi-stained neurons in the dorsal horn using a single $250 \mu \mathrm{m}$ transverse section containing the cell body. Thus, their findings cannot be compared to the present ones because they studied a different sample of neurons, with different inputs, uscd a wider rangc of postoperative times, and-perhaps most important-employed different staining procedures. It is quite clear that intracellular HRP reveals much more of the cell's dendritic processes than Golgi methods (Brown, 1981), and because only one cell is stained, identification of processes belonging to a given cell is not prone to error due to interdigitation of processes from different neurons. Furthermore, it seems likely that the HRP method gives more equivalent results in the intact and deafferented cord than does the Golgi method, which depends in an as-yet-unknown manner on cell surface properties that may be altered by the rhizotomy (Lynch and Gall, 1979; Lynch et al., 1975). In fact, our results correspond more closely to those of A. G. Brown and colleagues (1983), who also demonstrated relatively few changes in identified SCT cells following partial deafferentation. Those experiments, carried out with the intracellular HRP method, suggested a very modest expansion of the dendritic tree into the superficial layers of the dorsal horn, whereas in ours, the change in dorsally directed dendrites, if any, was in the opposite direction. Brown et al. (1983) did not describe an enhanced ventral dendritic projection into lamina $\mathrm{V}$, as our results suggested. We consider these differences to be small, given the sampling problem, perhaps due, in part, to the additional analytic precision possible in using the computer. Our detailed reconstructions also suggest that the total length of the dendritic processes was unchanged in the spared root preparation (L5, L6, S1, S2 cut; L7 spared), or even when all the dorsal roots supplying the lumbar enlargement (L5-S2) were cut. Rather, the dendrites may be redistributed with no change in total dendritic length.

Of potentially greater significance is our finding, again derived from computer reconstruction of HRP-filled neurons, that dendrites in the partially deafferented cord can display some signs of enlargement. Individual dendrites of several cells exhibited a higher branching order than the maximum observed in intact preparations. Furthermore, cells in these preparations had greater mean dendritic diameter than any of the neurons in the intact preparation (Table 1). Mean surface area and volume of individual dendritic trees were significantly greater after chronic partial deafferentation. Although these findings will require additional verification, they indicate that not all the changes following deafferentation are atrophic, as has been claimed in other systems (Benes et al., 1977; Brown et al., 1979; Chen and Hillman, 1982; Jones and Thomas, 1962; Mouran-Mathieu and Colonnier, 1969; Rubel et al., 1981; Smith, 1974; Sugimoto and Gobel, 1984). Perhaps it would be more profitable to think in terms of dendritic reorganization following partial deafferentation, which would consist of both retraction and expansion of different portions of the dendritic tree, e.g., a loss of dendrites in the denervated region, followed by expansion in the nondenervated region. Such a conclusion was reached recently by Cáceres and Steward (1983) in describing the dendritic tree of dentate granule cells following partial deafferentation. Reorganization of motoneuron dendrites following deafferentation by dorsal horn "mince" has been reported (Bernstein and Standler, 1983). Dendritic expansion might be a special case of sprouting, which has been described for axons that survive in a partially deafferented region (Cotman et al., 1981). In complex cells, the changes might be restricted to dendrites with a particular orientation and/or input (Brown et al., 1979; Rosenthal and Cruce, 1984). It is in this context that the increase in dendritic diameter, surface area, volume, and branch order, as well as in the shift toward relatively more ventral than dorsal and caudal than rostral dendrites after deafferentation, might be viewed. It must also be noted that our experiments were all carried out on cells that had been deafferented for 70-218 d. This may account for our failure to find any evidence for dendritic atrophy, which might be more pronounced at earlier or later times.

One of the major uncertainties in studies of this type is the degree of denervation to which the postsynaptic SCT cells have been subject. It is well known that these cells derive an important monosynaptic input from large cutaneous afferent fibers, particularly hair afferent fibers (Brown and Noble, 1982). Thus, cells in the L6 segment undoubtedly receive monosynaptic input from afferents entering in L7, given the widespread rostralcaudal projection of individual hair afferent fibers (Brown et al., 1977b). More difficult to assess is the degree to which these cells receive input from other neurons, from both intrinsic local connections and long-ranging ascending and descending fibers (Wall and Werman, 1976). Such connections may "protect" these neurons from the effects of dorsal rhizotomy; other cells, which undergo more drastic reorganization after deafferentation, may be dominated to a greater extent by the interfered-with input. These factors may contribute to some of the variability in our results.

In evaluating these results, we agree with Brown et al. (1983) that the changes after partial deafferentation are very modest when consideration is restricted to qualitative descriptions of dendritic orientation. Despite the similarity in mean total dendritic length and average numbers of primary dendrites for these two populations of SCT cells, the dendritic trees of SCT cells are much too variable for results from such a small sample to be conclusive. However, the use of computer reconstruction has revealed quantitative changes in dendritic diameter and maximum branch order that may be more reliable. Every dendrite of each cell has been completely reconstructed and analyzed; changes in diameter would have to be widespread in order to emerge from the analysis. It may be important, then, that the three cells with the highest proportion of ventrally directed dendrites had much larger mean dendritic diameters, and two of 
these had higher branching orders than any of the eight cells in intact preparations. Such differences are highly suggestive of dendritic alterations for at least some of thesc SCT ncurons. We would further argue that this reorganization could contribute to the increased probability of such cells' responding to nociceptive inputs, the major result obtained in physiological experiments on these preparations and in this subset of neurons when analyzed morphologically. However, it seems inevitable that other inputs must also contribute to these results of altered modality convergence; thus, it seems necessary to expand these investigations to the cells of the superficial layers, which are likely to mediate transmission from small-diameter primary afferents to SCT cells (Light and Kavookjian, 1984).

\section{References}

Barrett, J. N., and W. E. Crill (1974) Specific membrane properties of cat motoneurones. J. Physiol. (Lond.) 239: 301-324.

Beitel, R. E., and R. Dubner (1976) Responise of unmyelinated (C) polymodal nociceptors to thermal stimuli applied to monkey's face. J. Neurophysiol. 39: 1160-1175.

Benes, F. M., T. N. Parks, and E. W. Rubel (1977) Rapid dendritic atrophy following deafferentation: An E. M. morphometric analysis. Brain Res. 122: 1-13.

Bernstein, J. J., and N. A. Standler (1983) Dendritic alteration of rat spinal motoneurons after dorsal horn mince: Computer reconstruction of dendritic fields. Exp. Neurol. 82: 532-540.

Bessou, P., and E. R. Perl (1969) Response of cutaneous sensory units with unmyelinated fibers to noxious stimuli. J. Neurophysiol. 32 . 1025-1043.

Brown, A. G. (1981) Organization in the Spinal Cord. Springer-Verlag, New York.

Brown, A. G., and D. N. Franz (1969) Responses of spinocervical tract neurones to natural stimulation of identified cutaneous receptors. Exp. Brain Res. 7: 231-249.

Brown, A. G., and R. Noble (1982) Connexions between hair follicle afferent fibers and spinocervical tract neurones in the cat. J. Physiol. (Lond.) 323: 77-91.

Brown, A. G., C. R. House, P. K. Rose, and P. J. Snow (1976) The morphology of spinocervical tract neurones in the cat. J. Physiol. (Lond.) 260: 719-738.

Brown, A. G., P. K. Rose, and P. J. Snow (1977a) The morphology of spinocervical tract neurones revealed by intracellular injection of horseradish peroxidase. J. Physiol. (Lond.) 270: 747-764.

Brown, A. G., P. K. Rose, and P. J. Snow (1977b) The morphology of hair follicle afferent fiber collaterals in the spinal cord of the cat. J. Physiol. (Lond.) 272: 779-797.

Brown, A. G., R. E. W. Fyffe, R. Noble, P. K. Rose, and P. J. Snow (1980) The density, distribution and topographical organization of spinocervical tract neurones in the cat. J. Physiol. (Lond.) 300:409428.

Brown, A. G., P. B. Brown, R. E. W. Fyffe, and L. M. Pubols (1983) Effects of dorsal root section on spinocervical tract neurones in the cat. J. Physiol. (Lond.) 337: 589-608.

Brown, P. B., G. R. Busch, and Whittington (1979) Anatomical changes in cat dorsal horn cells after transection of a single dorsal root. Exp. Neurol. 64: 453-468.

Burgess, P. R., and E. R. Perl (1967) Myelinated afferent fibres responding specifically to noxious stimulation of the skin. J. Physiol (Lond.) 190: 541-562.

Cáceres, A., and O. Steward (1983) Dendritic reorganization in the denervated dentate gyrus of the rat following entorhinal cortical lesions: A golgi and electron microscopic analysis. J. Comp. Neurol. 214: 387-403.

Capowski, J. J. (1985) The reconstruction, display, and analysis of neuronal structures using a computer. In The Microcomputer in Cell and Neurobiology Research, R. R. Mize, ed., Elsevier, New York.

Capowski, J. J., and M. J. Sedivec (1981) Accurate computer reconstruction and graphics display of complex neurons utilizing state-ofthe-art interactive techniques. Comput. Biomed. Res. 14: 518-532.

Chen, S., and D. E. Hillman (1982) Marked reorganization of Purkinje cell dendrites and spines in adult rat following vacating of synapses due to deafferentation. Brain Res. 245: 131-135.
Cotman, C. W., M. Nieto-Sampedro, and E. W. Harris (1981) Synapse replacement in the nervous system of adult vertebrates. Physiol. Rev. 61: 684-784

Glaser, E. M. (1982) Snell's law: The bane of computer microscopists. J. Neurosci. Methods 5: 201-202.

Jones, W. H., and D. B. Thomas (1962) Changes in dendritic organization of neurons in the cerebral cortex following deafferentation. J. Anat. 96: 375-381.

Light, A. R., and A. M. Kavookjian (1984) Substantia gelatinosa neurons with axons projecting to other dorsal horn laminae. Soc. Neurosci. Abstr. 10: 489

Light, A. R., and E. R. Perl (1979a) Reexamination of the dorsal root projection to the spinal dorsal horn including observations on the differential termination of coarse and fine fibers. J. Comp. Neurol. 186: $117-132$.

Light, A. R., and E. R. Perl (1979b) Spinal termination of functionally identified primary afferent neurons in the marginal zone and substantia gelatinosa of the spinal dorsal horn. J. Comp. Neurol. 186: 133-150.

Light, A. R., D. L. Trevino, and E. R. Perl (1979) Morphological features of functionally defined neurons in the marginal zone and substantia gelatinosa of the spinal dorsal horn. J. Comp. Neurol. 186: 151-172.

Lynch, G., and C. Gall (1979) Organization and reorganization in the central nervous system: Evolving concepts of brain plasticity. In $\mathrm{Hu}$ man Growth, Vol. 3, F. Falkner and J. M. Tanner, eds., pp. 125-144, Plenum, New York.

Lynch, G., G. Rose, C. Gall, and C. W. Cotman (1975) The response of the dentate gyrus to partial deafferentation. In Golgi Centennial Symposium Proceedings, M. Santini, ed., pp. 505-517, Raven, New York.

Mendell, L. M. (1966) Physiological properties of unmyelinated fibre projections to the spinal cord. Exp. Neurol. 16: 316-332.

Mouran-Mathieu, S., and M. Colonnier (1969) The molecular layer of the adult cat cerebellar cortex after lesion of the parallel fibers: An optic and electron microscopic study. Brain Res. 16: 307-323.

Perl, E. R. (1968) Myelinated afferent fibres innervating the primate skin and their responses to noxious stimuli. J. Physiol. (Lond.) 197: 593-615.

Rall, W. (1977) Core conductor theory and cable properties of neurons. In Handbook of Physiology, Section 1: The Nervous System, Vol. 1: Cellular Biology of Neurons, E. R. Kandel, ed., pp. 39-97, American Physiological Society, Bethesda, MD.

Redman, S. J. (1976) A quantitative approach to the integrative function of dendrites. In International Review of Physiology: Neurophysiology II, Vol. 10, R. Porter, ed., pp. 1-36, University Park Press, Baltimore, MD.

Rexed, B. (1952) The cytoarchitectonic organization of the spinal cord in the cat. J. Comp. Neurol. 96: 415-493.

Rexed, B. (1954) A cytoarchitectonic atlas of the spinal cord in the cat. J. Comp. Neurol. 100: 297-379.

Ritz, L. A., and J. D. Greenspan (1985) Morphological features of lamina $\mathrm{V}$ neurons receiving nociceptive input in cat sacrocaudal spinal cord. J. Comp. Neurol. 239: 440-452.

Rosenthal, B. M., and W. L. R. Cruce (1984) Contralateral motoneuron dendritic changes induced by transection of frog spinal nerves. Exp. Neurol. 85: 565-573.

Rubel, E. W., Z. D. J. Smith, and O. Steward (1981) Sprouting in the avian brainstem auditory pathway: Dependence on dendritic integrity. J. Comp. Neurol. 202: 397-414.

Sedivec, M. J., J. J. Capowski, J. Ovelmen-Levitt, and L. M. Mendell (1982) Changes in dendritic organization of spinocervical tract neurons following partial chronic deafferentation. Soc. Neurosci. Abstr. 8: 755.

Sedivec, M. J., J. Ovelmen-Leavitt, R. Karp, and L. M. Mendell (1983) Increase in nociceptive input to spinalcervical tract neurons following chronic partial deafferentation. J. Neurosci. 3: 1511-1519.

Smith, D. E. (1974) The effect of deafferentation on the postnatal development of Clarke's nucleus in the kitten - a Golgi study. Brain Res. 74: 119-130.

Sugimoto, T., and S. Gobel (1984) Dendritic changes in spinal dorsal horn following transection of a peripheral nerve. Brain Res. 321: 199208.

Ulfhake, B. (1984) A morphometric study of the soma, first-order 
dendrites and proximal axon of cat lumbar $\alpha$-motoneurones intracellularly labelled with HRP. Exp. Brain Res. 56: 327-334.

Ulfhake, B., and J.-O. Kellerth (1981) A quantitative light microscopic study of the dendrites of cat spinal $\alpha$-motoneurons after intracellular staining with horseradish peroxidase. J. Comp. Neurol. 202: 571583.

Ulfhake, B., and J.-O. Kellerth (1984) Electrophysiological and morphological measurements in cat gastrocnemius and soleus $\alpha$-motoneurones. Brain Res. 307: 167-179.
Wall, P. D. and R. Werman (1976) The physiology and anatomy of long ranging afferent fibres within the spinal cord. J. Physiol. (Lond.) 255: 321-334.

Zwaagstra, B., and D. Kernell (1981) Sizes of soma and stem dendrites in intracellularly labelled $\alpha$-motoneurones of the cat. Brain Res. 204. 295-309. 